\title{
PENETAPAN KADAR KALIUM, KALSIUM, NATRIUM DAN \\ MAGNESIUM DALAM BUNGA NANGKA (Artocarpus eterophyllus Lam.) JANTAN SECARA SPEKTROFOTOMETRI SERAPAN ATOM
}

\author{
DETERMINATION OF POTASSIUM, CALCIUM, SODIUM AND \\ MAGNESIUM IN MALE JACKFRUIT FLOWERS (Artocarpus \\ heterophyllus Lam.) BY ATOMIC ABSORPTION \\ SPECTROPHOTOMETRY
}

\author{
Masfria*, Nanda Putri Maulidar, Ginda Haro \\ Departemen Kimia Farmasi, Fakultas Farmasi, Universitas Sumatera Utara, Medan \\ *Penulis Korespondesi, Email: fia.mustafa@yahoo.com
}

\begin{abstract}
ABSTRAK
Nangka merupakan salah satu buah tropis yang keberadaannya tidak mengenal musim. Tanaman nangka adalah tanaman berumah satu, artinya dalam satu tanaman dapat dijumpai bunga jantan dan bunga betina. Mineral memegang peranan penting dalam pemeliharaan fungsi tubuh secara keseluruhan. Mineral digolongkan dalalm mineral makro yang dibutuhkan dalam jumlah $100 \mathrm{mg}$ sehari dan mineral mikro kurang dari $100 \mathrm{mg}$ sehari. Bunga nangka kurang populer dikalangan masyarakat dan belum ada penelitian terdahulu yang meneliti tentang kandungan dalam sampel tersebut. Tujuan penelitian ini adalah untuk mengetahui kandungan mineral kalium, kalsium, natrium dan magnesium dalam bunga nangka jantan. Preparasi sampel dilakukan dengan proses dekstruksi kering. Penentuan kadar kalium, kalsium, natrium dan magnesium dilakukan dengan metode spektrofotometri serapan atom (SSA) masing-masing pada panjang gelombang $766,5 \mathrm{~nm} ; 422,7 \mathrm{~nm} ; 589,0 \mathrm{~nm}$ dan $285,2 \mathrm{~nm}$ dengan nyala udaraasetilen. Hasil penelitian menunjukkan bahwa kadar kalium, kalsium, natrium dan magnesium pada bunga nangka jantan yaitu $[530,810] \pm 2,760 \mathrm{mg} / 100 \mathrm{~g} ;[54,928]$ $\pm 0,519 \mathrm{mg} / 100 \mathrm{~g} ;[16,087] \pm 1,208 \mathrm{mg} / 100 \mathrm{~g}$ dan $[16,653] \pm 0,205 \mathrm{mg} / 100 \mathrm{~g}$.
\end{abstract}

Kata kunci: bunga nangka jantan, kalium, kalsium, natrium, magnesium, spektrofotometri serapan atom.

\section{ABSTRACT}

Jackfruit is one of the tropical fruit whose existence is not familiar with the season. Jackfruit plant is a single-rooted plant, meaning that in one plant can be found male flowers and female flowers. The flower appears on the leaf's armpits on short, special shoots that grow on the sides of the stems or old branches. Male flowers have a slim shape. Jackfruit flowers are less popular among the community and no previous research has examined the content in the sample. The 
purpose of this study was to determine the mineral content of potassium, calcium, sodium and magnesium in male jackfruit flowers. Sample preparation was done by dry destruction process. Determination of potassium, calcium, sodium and magnesium levels was performed by atomic absorption spectrophotometry (AAS) method at $766.5 \mathrm{~nm}$ wavelength; $422.7 \mathrm{~nm} ; 589.0 \mathrm{~nm}$ and $285.2 \mathrm{~nm}$ with an airacetylene flame. The results showed that potassium, calcium, sodium and magnesium levels in male jackfruit flower is [530.810] $\pm 2.760 \mathrm{mg} / 100 \mathrm{~g}$; [54.928] $\pm 0.519 \mathrm{mg} / 100 \mathrm{~g} ;[16.087] \pm 1.208 \mathrm{mg} / 100 \mathrm{~g}$ and $[16.653] \pm 0.205 \mathrm{mg} / 100 \mathrm{~g}$

Keywords: male jackfruit flower, potassium, calcium, sodium, magnesium, atomic absorption spectrophotometry.

\section{PENDAHULUAN}

Nangka merupakan salah satu buah tropis yang keberadaannya tidak mengenal musim. Di Indonesia, pohon nangka dapat tumbuh hampir di setiap daerah. Menurut Kementerian Pertanian Indonesia (2014), produksi nangka di Indonesia pada tahun 2011-2013 berturut-turut mencapai 654,808; 663,930; dan 586,356 ton. Buah nangka terdiri dari beberapa pulp kuning dan biji cokelat yang terbungkus dalam kulit keras, mengandung karbohidrat, vitamin B kompleks dan mineral (Madruga dkk., 2014).

Menurut USDA (2008), nilai gizi tiap 100 gram buah nangka adalah kalium $303 \mathrm{mg}$, kalsium $34 \mathrm{mg}$, natrium $3 \mathrm{mg}$, magnesium $37 \mathrm{mg}$, serta karbohidrat, protein, kolesterol, mineral dan vitamin. Mineral merupakan kebutuhan tubuh manusia yang mempunyai peranan penting dalam pemeliharaan fungsi tubuh, seperti untuk pengaturan kerja enzim-enzim, pemeliharaan keseimbangan asam-basa, membantu pembentukan ikatan yang memerlukan mineral seperti pembentukan hemoglobin (Almatsier, 2004).

Kadar mineral yang tinggi di dalam buah nangka dapat meningkatkan taraf kesehatan bagi yang mengkonsumsi buah tersebut antara lain kalium berperan dalam transmisi dan konduksi impuls-impuls saraf, kontraksi otot-otot rangka, otot jantung dan otot polos. (Kee dan Evelyn, 1996). Kalsium berfungsi meningkatkan aktivitas saraf, kontraksi otot jantung (miokardium), mempertahankan permeabilitas seluler normal dan membantu pembekuan darah dengan mengubah protrombin menjadi thrombin, selain itu kalsium juga dibutuhkan untuk pembentukan tulang dan gigi (Kee dan Evelyn, 1996). Natrium mengatur tekanan osmotik dari cairan ekstraseluler dan secara nyata mempengaruhi tekanan osmotik cairan intraseluler. Oleh karena itu mineral ini sangat berperan dalam pengaturan cairan tubuh termasuk tekanan darah, kepekaan konduksi dari syaraf dan jaringan otot serta pengaturan keseimbangan asam basa (Horne, 2000). Magnesium berfungsi memperkuat tulang, melawan radikal bebas, menyehatkan jantung, menurunkan tekanan darah dan mencegah diabetes. Kekurangan mineral ini menyebabkan kemunculan tanda-tanda penuaan lebih dini (Fatmah, 2010).

Berdasarkan uraian di atas, penetapan kadar kalium, kalsium, natrium dan magnesium yang terdapat pada bunga nangka jantan menggunakan spektrofotometri serapan atom. 


\section{METODE PENELITIAN}

Alat

Alat-alat yang digunakan dalam penelitian ini adalah Spektrofotometri Serapan Atom (Shimadzu AA-7000) dengan nyala udara asetilen lengkap dengan lampu katoda $\mathrm{K}, \mathrm{Ca}, \mathrm{Na}$ dan $\mathrm{Mg}$, neraca analitik (BOECO), tanur (Stuart), hot plate, kertas saring Whatman no. 42, krus porselen, blender, spatula, botol kaca dan alat-alat gelas lainnya (Pyrex dan Oberol).

Bahan

Bahan yang digunakan adalah bunga nangka jantan, $\mathrm{HNO}_{3} \quad 65 \% \mathrm{~b} / \mathrm{v}$ (E.Merck), larutan standar kalium $(1000 \mu \mathrm{g} / \mathrm{ml})$ (E.Merck), larutan standar kalsium (1000 $\mu \mathrm{g} / \mathrm{ml})($ E.Merck), larutan standar natrium $(1000 \mu \mathrm{g} / \mathrm{ml})($ E.Merck), larutan standar magnesium (1000 $\mu \mathrm{g} / \mathrm{ml})($ E.Merck), $\mathrm{CsCl}($ E.Merck), $\mathrm{La}_{2} \mathrm{O}_{3}$ (E.Merck), larutan kuning titan $0,1 \%, \mathrm{NaOH} 2 \mathrm{~N}, \mathrm{H}_{2} \mathrm{SO}_{4} 1 \mathrm{~N}$ dan akuademineralisata (Laboratorium Balai Riset dan Standardisasi Industri Medan).

Pengambilan Sampel

Sampel yang digunakan adalah bunga nangka jantan yang diambil secara purposif dari pohon nangka di Langsa, Aceh Timur.

Penyiapan Sampel

Sebanyak \pm 250 g bunga nangka jantan dibersihkan dari bagian kulit dengan cara mengupasnya, dicuci bersih lalu ditiriskan, dikeringkan dengan cara diangin-anginkan. Selanjutnya diiris kecil-kecil dan dihaluskan dengan blender.

\section{Proses Destruksi Kering}

Sampel yang telah dihaluskan masing-masing ditimbang sebanyak $\pm 25 \mathrm{~g}$, didalam krus porselen, diarangkan diatas hot plate pada suhu $200^{\circ} \mathrm{C}$, lalu diabukan dengan tanur pada temperature awal $100^{\circ} \mathrm{C}$ dan dinaikkan perlahan-lahan hingga $500^{\circ} \mathrm{C}$ dengan interval $25^{\circ} \mathrm{C}$ setiap 5 menit. Pengabuan dilakukan selama 24 jam dan dibiarkan hingga dingin didalam tanur hingga suhu tanur mencapai suhu ruangan $\pm 27^{\circ} \mathrm{C}$ (Isaac, 1990).

\section{Pembuatan Larutan Sampel}

Sampel hasil destruksi ditambahkan $5 \mathrm{ml} \mathrm{HNO}_{3}(1: 1)$, lalu dimasukkan ke dalam labu tentukur $100 \mathrm{ml}$, krus porselen dibilas hingga tiga kali kemudian larutan dicukupkan dengan akuademineralisata hingga garis tanda dan dihomogenkan. Selanjutnya larutan disaring dengan kertas Whatman no. 42 dan 5 $\mathrm{ml}$ filtrat pertama dibuang untuk menjenuhkan kertas saring kemudian filtrat selanjutnya ditampung dalam wadah botol kaca.

\section{Analisis Kualitatif dan Kuantitatif}

Analisis kualitatif dan kuantitatif dilakukan terhadap kalium, kalsium, natrium dan magnesium. Uji nyala digunakan untuk menentukan analisis kualitatif kalium, kalsium dan natrium, uji kristal kalium dengan asam pikrat, uji kristal kalsium dengan asam sulfat $1 \mathrm{~N}$, uji kristal natrium dengan asam pikrat dan uji 
magnesium dengan reagensia kuning titan (Vogel, 1985). Analisis kuantitatif dilakukan menggunakan alat spektrofotometer serapan atom.

Perhitungan Kadar Kalium, Kalsium,Natrium dan Magnesium dalam Sampel

Kadar kalium, kalsium, natrium dan magnesium dalam sampel dapat dihitung dengan cara berikut:

$$
\begin{gathered}
\text { Kadar mineral }\left(\frac{\mu g}{\mathrm{ml}}\right)= \\
\frac{\text { konsentrasi }(\mu \mathrm{g} / \mathrm{ml}) \times \text { volume }(\mathrm{ml}) \times \text { faktor pengenceran }}{\text { berat sampel }(\mathrm{g})}
\end{gathered}
$$

\section{Analisis Data}

Analisisi data dilakukan dalam bentuk rata-rata \pm SD berdasarkan uji penentuan batas deteksi (Limit of Detection), batas kuantitasi (Limit of Quantitation), uji perolehan kembali (recovery) (Harmita, 2004).

\section{HASIL DAN PEMBAHASAN}

Identifikasi Tumbuhan

Identifikasi tumbuhan dilakukan di Laboratorium Taksonomi Tumbuhan, Departemen Biologi, Fakultas Matematika dan Ilmu Pengetahuan Alam, Universitas Sumatera Utara, Medan. Hasil identifikasi menunjukkan bahwa tumbuhan yang digunakan adalah bunga nangka dengan jenis Artocarpus heterophyllus Lam. dari suku Moraceae.

\section{Analisis Kualitatif}

Analisis kualitatif dilakukan sebagai analisis pendahuluan untuk mengetahui secara kualitatif mineral kalium, kalsium, natrium dan magnesium. Hasil penelitian menunjukkan bahwa sampel bunga nangka jantan mengandung mineral kalium, kalsium, natrium dan magnesium (Tabel 1).

Tabel I. Hasil Analisis Kualitatif Kalium, Kalsium, Natrium dan Magnesium dalam Bunga Nangka Jantan

\begin{tabular}{ccccc}
\hline No & Mineral & Pereaksi & Hasil Reaksi & Hasil \\
\hline 1 & Kalium & Uji nyala & Warna ungu & + \\
& Asam pikrat & Kristal jarum besar & + \\
2 & Uji nyala & Warna merah bata & + \\
& & $\mathrm{H}_{2} \mathrm{SO}_{4}$ 1 N dan etanol $96 \%$ & Kristal jarum & + \\
3 & Natrium & Uji nyala & Warna kuning & + \\
& & Asam pikrat & Kristal jarum kecil & + \\
4 & Magnesium & NaOH 2 N + kuning & Endapan warna & + \\
& & titan $(0,1 \%$ b/v $)$ & merah & \\
\hline
\end{tabular}

Keterangan : (+)mengandung mineral 


\section{Analisis Kuantitatif}

Kurva Kalibrasi Kalium, Kalsium, Natrium dan Magnesium

Kurva kalibrasi kalium, kalsium, natrium dan magnesium diperoleh dengan cara mengukur absorbansi dari larutan standar pada panjang gelombang $766,5 \mathrm{~nm}$ untuk kalium, 422,7 $\mathrm{nm}$ untuk kalsium, 589,0 $\mathrm{nm}$ untuk natrium dan 285,2 nm untuk magnesium. Dari pengukuran kurva kalibrasi diperoleh persamaan garis regresi yaitu $\mathrm{Y}=0,602 \mathrm{X}+0,096$ untuk kalium, $\mathrm{Y}=0,076 \mathrm{X}+0,022$ untuk kalsium, $\mathrm{Y}=0,787 \mathrm{X}+0,123$ untuk natrium dan $\mathrm{Y}=3,821 \mathrm{X}+0,013$ untuk magnesium.

Berdasarkan kurva kalibrasi, diperoleh hubungan yang linier antara konsentrasi dengan absorbansi, dengan koefisien korelasi (r) kalium sebesar 0,9999, kalsium sebesar 0,9998, natrium sebesar 0,9975 dan magnesium sebesar 0,9999. Nilai $r \geq 0,97$ menunjukkan adanya korelasi linier yang menyatakan adanya hubungan antara X (konsentrasi) dan Y (absorbansi) (Ermer dan John, 2005).

Analisis Kadar Kalium, Kalsium, Natrium dan Magnesium dalam Sampel

Penentuan kadar kalium, kalsium, natrium dan magnesium dilakukan secara spektrofotometri serapan atom. Konsentrasi logam kalium, kalsium, natrium, dan magnesium dalam sampel ditentukan berdasarkan persamaan garis regresi kurva kalibrasi larutan standar masing-masing mineral. Hasil analisis kuantitatif kadar kalium, kalsium, natrium, dan magnesium dapat dilihat pada Tabel II..

Tabel II. Hasil Analisis Kuantitatif Kadar Kalium, Kalsium, Natrium dan Magnesium dalam Bunga Nangka Jantan

\begin{tabular}{cc}
\hline Mineral & Kadar (mg/100g) Bunga Nangka Jantan \pm \\
SD
\end{tabular}

Data pada Tabel II menunjukkan bahwa bunga nangka jantan mengandung kalium, kalsium, natrium dan magnesium. Kandungan mineral dapat dimanfaatkan dalam kesehatan untuk menurunkan tekanan darah, memperkuat tulang, menyehatkan jantung, mengatur pembekuan darah dan menjaga keseimbangan cairan dan elektrolit dalam tubuh. Untuk kandungan mineral pada bunga nangka jantan belum ada literatur yang menyatakan berapa jumlah kadarnya, sehingga penelitian ini dapat menjadi referensi untuk mengetahui kadar mineral kalium, kalsium, natrium dan magnesium pada bunga nangka jantan.

Bunga nangka secara umum sulit diperoleh, oleh karena itu untuk mendapatkan kandungan mineral yang sama dengan bunga nangka agar dapat dimanfaatkan dalam kesehatan dapat digunakan tumbuhan lain yang kandungan 
mineralnya mirip dengan bunga nangka. Misalnya kandungan kalium dalam ubi jalar $(550 \mathrm{mg} / 100 \mathrm{~g})$. Kandungan kalsium yang mirip dengan bunga nangka seperti buah jeruk $(50 \mathrm{mg} / 100 \mathrm{~g})$, brokoli $(60 \mathrm{mg} / 100 \mathrm{~g})$.Kandungan natrium yang mirip dengan bunga nangka seperti pir (kering) $(13 \mathrm{mg} / 100 \mathrm{~g})$.

Tanaman nangka adalah tanaman berumah satu, artinya dalam satu tanaman dapat dijumpai bunga jantan dan bunga betina. Bunga jantan dicirikan dengan bentuknya yang langsing, bengkok, dan berwarna hijau tua. Sedangkan bunga betina dicirikan dengan bentuknya yang gemuk dan berwarna hijau (Anonim, 2007). Bunga nangka jantan memiliki rasa kelat dan juga dijadikan obat tradisional untuk diare. Kandungan dari nangka dapat saja berbeda hal ini dapat dipengaruhi oleh beberapa faktor seperti tempat tumbuh tanaman, kesuburan tanaman, perlakuan terhadap tanaman dan iklim (Rosmarkam dan Nasih, 2002).

Proses atomisasi logam-logam ini digunakan bahan bakar dan bahan pengoksida yaitu udara asetilen. Suhu campuran bahan bakar ini adalah sekitar $2200^{\circ} \mathrm{C}$ (Ganjar dan Abdul, 2012). Suhu ini tidak dapat membuat senyawa kalium, natrium, kalsium dan magnesium menjadi atom netral, dikarenakan atom mineral tersebut bersifat refractory atau sukar terurai. Untuk mengatasi hal ini, dalam pengerjaannya perlu ditambahkan suatu senyawa yaitu lanthanum oksida $\left(\mathrm{La}_{2} \mathrm{O}_{3}\right)$ untuk mineral kalsium dan magnesium serta penambahan senyawa cesium klorida $(\mathrm{CeCl})$ untuk mineral kalium dan natrium, sehingga senyawa yang bersifat refractory tersebut mudah terlepas dari senyawanya dan menjadi atom netral.

Senyawa penyangga akan mengikat gugusan pengganggu (silikat, fosfat, aluminat, sulfat dan sebagainya). Contoh unsur penyangga adalah $\mathrm{Sr}$ dan La yang ditambahkan pada analisis $\mathrm{Ca}$ secara belum muncul di kalimat sebelumnya. Penambahan senyawa penyangga ini maka ion fosfat akan terikat dan tidak akan membentuk Ca-fosfat yang bersifat refraktoris. Sementara itu, untuk menghindari pengaruh gangguan karena ionisasi dapat ditambahkan unsur lain yang mempunyai potensial yang lebih rendah dari unsur yang dianalisis (Gandjar dan Abdul, 2012).

Pada logam magnesium dapat mengalami gangguan kimiawi biasa terjadi pada nyala udara-asetilena. Penambahan agen pelepas (strontium atau lanthanum) membantu menghilangkan gangguan tersebut (Antanasopoulos, 1996). Pada logam kalium dapat mengalami gangguan ionisasi dalam nyala api asetilena dikurangi dengan penambahan cesium, natrium atau rubidium. Sedangkan pada logam natrium dapat mengalami gangguan terionisasi sebagian dalam nyala asetilena udara. Penambahan cesium atau kalium klorida pada konsentrasi akhir akan menekan ionisasi (Antanasopoulos, 1996).

\section{KESIMPULAN DAN SARAN}

Berdasarkan hasil penelitian dapat disimpulkan bahwa bunga nangka jantan mengandung mineral kalium, kalsium, natrium dan magnesium dengan kadar yaitu $[530,381] \pm 2,760 \mathrm{mg} / 100 \mathrm{~g} ;[54,928] \pm 0,519 \mathrm{mg} / 100 \mathrm{~g} ;[16,087] \pm$ $1,208 \mathrm{mg} / 100 \mathrm{~g}$ dan $[16,653] \pm 0,205 \mathrm{mg} / 100 \mathrm{~g}$

\section{DAFTAR PUSTAKA}

Almatsier, S., 2004, Prinsip Dasar Ilmu Gizi, Jakarta: PT. Gramedia Pustaka Utama, Hal. 228. 
Antanasopoulos, N., 1996, Flame Methods Manual For Atomic Absorption, GBC Science Eq, Pty Ltd, Dandenong, Australia.

Devi, N,. 2010, Nutrition and Food Gizi Untuk Keluarga, Jakarta: Buku Kompas, Hal. 94.

Dirjen POM., 1979, Farmakope Indonesia, Edisi Ketiga, Jakarta: Departemen Kesehatan Republik Indonesia, Hal.412, 650 dan 745.

Ermer, J., John, H. M., 2005, Analytical Validation Within the Pharmaceutical Environment, Dalam: Ermer, J., dan Miller, J. H. McB., Editors. Method Validation in Pharmaceutical Analysis. Weinheim: Wiley-VCH Verlag GmbH \& Co. Hal. 3-5.

Fatmah, 2010, Gizi Usia Lanjut. Jakarta: Penerbit Erlangga. Hal.133-134.

Gandjar, I. G., Abdul, R., 2012, Kimia Farmasi Analisis, Cetakan Kesepuluh. Yogyakarta: Pustaka Pelajar, Hal. 298-322; 456; 463-473.

Harmita, 2004, Petunjuk Pelaksanaan Validasi Metode dan Cara Perhitungannya, Review Artikel, Majalah Ilmu Kefarmasian. 1 (3): 117-135.

Isaac, R. A., 1990, Metal in Plants: Atomic Absorption Spectrophotometric Method. Disunting Oleh: Helrich, K.,1990, Official Methods Of the Association Of Official Analytical Chemist, Edisi Kelimabelas. Virginia: AOAC International. Hal. 42.

Khopkar, S. M., 1990, Konsep Dasar Kimia Analitik, Penerjemah: Saptoraharjo, Jakarta: UI Press. Hal. 283.

Madruga,D 2014. Chemical, Morphological and Functional Properties of Brazilian Jackfruit (Artocarpus heterophyllus L.) Seeds Starch.Hal. 1.

Rosmarkam, A., Nasih, W. Y., 2002. Ilmu Kesuburan Tanah. Yogyakarta: Kanisius. Hal. 29.

Sudjana, 2005, Metode Statistika. Edisi Keenam. Bandung: Tarsito. Hal. 168-254.

Vogel, 1985, Buku Teks Analisis Anorganik Kualitatif Makro dan Semimikro. Edisi Kelima. Bagian Kedua. Penerjemah: Setiono dan Hadyana. Jakarta: Kalman Media Pustaka. Hal. 300; 302-311. 